\title{
Research on Accounting Policy Choice of High and New Technology Enterprises
}

\author{
Tang Dingfen \\ Department of Financial Management, Changchun Sci-Tech University, Chang Chun, 130022, China \\ 19465537@qq.com
}

Keywords: Accounting policy; Technology enterprises; knowledge-intensive; technology-intensive

\begin{abstract}
High-tech enterprises are knowledge-intensive and technology-intensive industries. Different accounting policy choices have different results on financial measurement, and also have different impacts on the development of enterprises. Under such circumstances, the development of enterprises needs more and more high-quality accounting information quality for decision-making, and the improvement of accounting information quality depends on the choice of accounting policy. This paper studies the accounting policy of high-tech industry, expounds the present situation and existing problems of its accounting policy choice, and analyzes the reasons affecting its accounting policy, and puts forward corresponding suggestions for improvement on this basis.
\end{abstract}

\section{Introduction}

High-tech enterprises generally refer to enterprises with core high-tech enterprises, which has a large scale investment in the early stage of research and development, such as manpower and capital. But once its research and development are successful, it will get higher economic benefits and obtain rich returns. This kind of enterprise is also different from the conventional enterprise when it carries on the enterprise financial accounting. Higher early cost input and later higher profit return require the enterprise to fully reflect the enterprise's operating conditions and financial results, improve the efficiency of enterprise accounting management and the quality of enterprise accounting information. It is very important to choose the accounting policy on this basis. The choice of accounting policies of high-tech enterprises will produce different results for the financial results of enterprises. On the one hand, the choice of accounting policy can simplify the financial work of the enterprise, and it is convenient for the financial personnel to compile accounting statements by choosing a simpler accounting policy calculation method; on the other hand, the different choice of accounting policy can affect the accounting of the financial profit of the enterprise, and then affect the taxable amount of the enterprise. The calculation and the level of tax burden that enterprises should bear. Choosing a suitable accounting policy for the actual development of enterprises is not only conducive to improve financial efficiency, but also reduce the level of tax that enterprises should bear. Therefore, enterprises should consider the actual situation and balance the interests of stakeholders to choose suitable accounting policies for their own development.

\section{Problems in Accounting Policy Choice of High and New Technology Enterprises}

\subsection{Accounting Policy Choice is Too Simple.}

The choice of accounting policies for high-tech enterprises is relatively simple. At present, some high-tech enterprises basically have the same choice of accounting policy, and there is no much difference. Only individual enterprises have different choice in some unique business. Most of the high-tech companies adopt the straight-line depreciation method to depreciate the fixed assets, but seldom choose the accelerated depreciation method. The weighted average pricing method is adopted in the selection of the valuation of inventory. The operation is relatively simple and convenient. These accounting policy choices are too simple, and do not really consider their own business model 
and industry characteristics from the actual business of the enterprise, which will directly affect the cost of the enterprise, thereby affecting the profits of the enterprise. In addition, in the complex market economy environment, if enterprises do not innovate and develop, not choose their own accounting policy, it is bound to have a certain impact on the long-term development of enterprises.

\subsection{No Consideration about the Integrity of Enterprises.}

For enterprises, the choice of accounting policy should fully consider the integrity of the enterprise, which will not only directly affect the measurement of accounting items, but also lead to changes in the relevant financial indicators of the enterprise. Especially for high-tech enterprises, their inherent industry characteristics determine that the choice of accounting policy must be suitable for the industry characteristics and their own business model, considering the integrity of the enterprise and the entire industry. However, from the research of high-tech enterprises, it is found that at present, high-tech companies do not pay attention to the overall optimization of the choice of accounting policies for enterprises. In the financial report of 2017, only the investment real estate measurement method is changed from cost method to fair value measurement. Other accounting subjects are copied from the relevant provisions of accounting standards, and do not fully consider the characteristics of the industry. This leads to its accounting policy choice process does not achieve the overall optimization of corporate financial objectives.

\subsection{No Consideration about the Industry Characteristics.}

The inherent industry characteristics of high-tech enterprises determine that the choice of accounting policy must be suitable for the industry characteristics. But the investigation of high-tech companies shows that the choice of the same accounting policy is basically the same, and there is no difference. This shows that the choice of accounting policy does not fully consider the characteristics of the industry, according to the nature of the industry to choose the accounting policy suitable for their own business development needs. Accounting policy choice should not only fully consider the characteristics of the industry in which the enterprise is located, but also make different accounting policy choices according to its own financial situation and the actual situation of the industry.

\section{Analysis of the Reasons Affecting the Accounting Policy Choice of High and New Technology Enterprises.}

\subsection{External Reasons for Enterprise's Accounting Policy Choice.}

\subsubsection{Imperfect Content of Accounting Standard System.}

From a macro perspective, the formulation of accounting standards and accounting systems in China is lagging behind. Although, with the continuous development of the economy and society, in order to adapt to the ever-changing requirements of accounting measurement of economic events, the new accounting standards and systems are constantly updated, but its update speed still cannot keep up with the requirements of economic development, resulting in a certain degree of lag in the accounting system. In addition, the current accounting standards give greater freedom of choice to enterprises to, which is conducive to enterprises to choose according to their own development, but at the same time this excessive choice makes enterprises arbitrarily carry out accounting policies and accounting estimates changes, the lack of a certain normative. In the final analysis, this is due to the imperfect accounting standard system.

\subsubsection{Insufficient Supervision of Regulatory Authorities.}

The supervision and management of the financial administrative department of an enterprise is a powerful guarantee for the enterprise to standardize the financial process, make reasonable accounting policy choices and make financial disclosure. However, the current supervision and management departments have some regulations and requirements on the daily financial supervision of enterprises. There are no specific procedures and clear provisions on the disclosure of financial 
information and the choice of accounting policies. For listed companies, the disclosure management regulations of listed companies should be carried out on the disclosure of relevant information of listed companies. For the non-listed companies, they can choose not to publish the financial information of the enterprise when announcing the annual information of the enterprise, which leads to a great opportunism in the choice of accounting policy because of the weak supervision. In addition, the financial, securities and other regulatory departments do not punish enterprises for violating the relevant provisions of accounting information disclosure enough, resulting in lower cost of violations, and cannot fundamentally curb the occurrence of disorderly accounting policy choices.

\subsection{Internal Reasons for Enterprise Accounting Policy Choice.}

\subsubsection{Deficiencies in Corporate Governance Structure.}

Corporate governance structure is the daily organizational structure of internal management, which determines the daily management of enterprises. The choice of accounting policy of enterprises is carried out under the corporate governance structure, but there are many deficiencies in the corporate governance structure of high-tech enterprises at present. High-tech enterprises put too much emphasis on the research and development of products and the acquisition of related patented technology. As a result, the company is not based on the public. The department's actual and market economic development needs to make timely and reasonable adjustments to their own organizational structure. At the same time, for the sake of saving costs and maximizing their own interests, high-tech enterprises, as high-input type, deal with accounting policies from the perspective of interest groups too much. In addition, due to the insufficiency of corporate governance structure, the management of enterprises has not realized the importance of optimizing the financial behavior of enterprises from the perspective of accounting policy choice, resulting in a single choice of accounting policy.

\subsubsection{Low Level of Accountants' Moral Quality and Knowledge.}

With the development of the market economy system, the economic transaction system has been perfected, and accordingly, the handling of accounting matters in the process of communication has become increasingly complex. This requires enterprise accountants to have a higher level of professional knowledge and moral quality in response to this increasingly complex financial management work. At the same time, in order to adapt to the ever-developing requirements of accounting matters, China has issued new accounting standards and accounting system, which requires the financial personnel of enterprises to constantly update their knowledge to meet the new requirements of accounting measurement. However, at present, most enterprises have no awareness of accounting policy choice. It is not easy for ordinary accountants to be familiar with accounting standards and accounting system requirements, and to operate according to the requirements, let alone to use professional accounting knowledge and skills to select accounting policies suitable for enterprises according to the actual operation. At present, due to the low level of accountants' knowledge and inadequate business skills, enterprises have some blindness and irrationality in the choice of accounting policies.

\subsubsection{Weak Internal Supervision Mechanism.}

As an important function of enterprise management, the internal supervision mechanism has an important direct impact on the survival and development of enterprises. From the point of internal supervision mechanism of high-tech companies, the internal accounting control mechanism is not perfect, and the unreasonable communication mechanism causes problems in the internal operation of enterprises. At present, the internal audit system of most high-tech enterprises is not perfect, and does not really play the role of internal supervision and management, resulting in the choice of accounting policy in a formality, randomness, and excessive consideration of maximizing the interests of the company, ignoring the normative choice of accounting policy. Internal audit plays an important role in internal supervision and management of enterprise internal control. Enterprises should strengthen the internal supervision mechanism, give full play to the role of supervision, and strengthen the 
supervision and management of enterprise internal accounting activities.

\section{Suggestions on Perfecting Accounting Policies of High and New Technology Enterprises}

\subsection{Further Optimizing and Perfecting Accounting Standard System.}

In view of the phenomenon that the content of accounting standard system is not perfect, first of all, we should perfect accounting standards, policies and regulations, establish an accounting standard system which is similar to international accounting standards, so that the accounting items established by the accounting standards and accounting systems are universal, and try our best to balance the various stakeholders of enterprises, and eliminate the causes of enterprises. There is a large discrepancy between the accounting methods adopted by the relevant accounting policies. Secondly, under the guidance of enterprise accounting standards, it is necessary to restrict the choice of enterprise accounting policies and the conditions for their change. On the one hand, with the continuous development of market economy, it is necessary to give enterprises some autonomy in choosing accounting policies, but at the same time, it is also necessary to appropriately choose their right and scope of choice. Choice of conditions for certain restrictions to prevent enterprises from excessive use of accounting policy options for fraud. Furthermore, to standardize the disclosure of enterprise accounting policies, enterprises are required to specify the basis and content of accounting policy choice in the statement of financial statements, so as to improve the overall grasp of enterprise accounting information.

\subsection{Strengthening Supervision by Various Regulatory Departments.}

Strengthen the supervision and inspection of enterprise accounting policies to ensure that enterprise accounting work in strict accordance with the accounting system and accounting standards. Therefore, the company should constantly strengthen supervision and management, the internal enterprise should not only have a sound accounting control system to strengthen supervision, but also to establish a complete information communication and exchange mechanism, so that the transmission of information, exchange can proceed smoothly. Firstly, we should supervise and perfect the internal control system of enterprise accounting, supervise the accounting information and events of the enterprise, especially examine the choice of accounting policy to see whether the choice of relevant policies conforms to the actual financial management of the company, have a significant impact on the enterprise, and solve the problems in time. Secondly, we should constantly improve the quality of enterprise accounting information, strengthen the control of enterprise accounting system, establish an efficient communication mechanism to ensure that all the work is done with a dedicated person responsible for, approve, supervise, and the information can be effectively transmitted among the three. And strengthen communication between internal and external businesses, strengthen business cooperation and market development.

\subsection{Improving Corporate Governance Structure and Strengthening Internal Supervision and Management.}

The choice of enterprise accounting policy is not only the application of accounting policy by the financial department of the enterprise, but also the management of the enterprise. The governance structure of the company restricts the choice of accounting policy and the choice of accounting policy. Therefore, it is necessary to constantly optimize the corporate governance structure, enhance corporate governance capacity, and ensure that enterprises choose appropriate accounting policies in the process of business management. Secondly, in order to give full play to the supervisory role of the Audit Supervision Department and the independent directors, the first step is to formulate and improve the internal audit system and equip professional personnel so that they can carry out the internal audit work according to the internal audit system; secondly, to supervise and spot check the financial work of the enterprise periodically or irregularly, and form the corresponding. Audit work report, risk assessment of various financial work, timely correction of the existing problems to ensure 
that financial work is legitimate, compliance, stable and orderly.

\subsection{Increasing the Education of Financial Personnel and Enhancing the Knowledge Level of Financial Personnel.}

The level of knowledge and business skills of financial personnel in enterprises have no direct impact on the due process of accounting matters, but also on the quality of financial information and the judgment of accounting policy choice, thus affecting the financial decision-making of enterprises. Therefore, only by comprehensively improving the quality and ability of the relevant personnel, the financial staff of the enterprise will be strong, and the correct choice and judgment can be made in the financial management decision-making of the enterprise. Therefore, enterprises should increase the education of their financial personnel, so that they can master the financial operation skills and relevant provisions of the current accounting regulations. Especially for high-tech enterprises, their business operation is more unique, and the choice of accounting policy is different from the general conventional enterprises, which requires financial personnel to have professional business skills. At the same time, to build a reasonable team building, to actively implement the "old with new" to avoid some people leaving the enterprise, new employees cannot understand the financial situation of the enterprise. In addition, we should strengthen the moral quality education of financial personnel and prevent the occurrence of favoritism. In short, enterprises must pay attention to the construction of financial personnel, to improve the quality and ability of financial personnel.

\section{References}

[1] Wang Ning. Corporate governance and accounting policy choice [M]. China Book Publishing House, 2018.

[2] Ren Junjie. Research on the accounting policy choice behavior of listed companies [M]. Economic Science Press, 2015.

[3] Chen Jichu. Research on the choice of enterprise accounting policy [M]. Southwestern University of Finance and Economics Press, 2009.

[4] Dai Feng Xiang. Research on the choice of enterprise accounting policies [M]. China Financial and Economic Publishing House, 2007.

[5] Compiling group of textbooks on continuing education and training for accountants. Interpretation of the latest policies on enterprise accounting standards [M], China Financial and Economic Press, 2015.

[6] Wang Yuhui. Research on accounting policy choice of innovative enterprises [J]. Friends of Accounting, 2012 (6). 